University of Nebraska - Lincoln

DigitalCommons@University of Nebraska - Lincoln

\title{
Correlation of a-Amylase Inhibitor Content in Eastern Soft Wheats with Development Parameters of the Rice Weevil (Coleoptera: Curculionidae)
}

\author{
James E. Baker \\ USDA-ARS \\ Stanley M. Woo \\ USDA-ARS \\ James E. Throne \\ USDA-ARS, Manhattan, KS, james.throne@ars.usda.gov \\ Patrick L. Finney \\ USDA-ARS
}

Follow this and additional works at: https://digitalcommons.unl.edu/usdaarsfacpub

Baker, James E.; Woo, Stanley M.; Throne, James E.; and Finney, Patrick L., "Correlation of a-Amylase Inhibitor Content in Eastern Soft Wheats with Development Parameters of the Rice Weevil (Coleoptera: Curculionidae)" (1991). Publications from USDA-ARS / UNL Faculty. 1998.

https://digitalcommons.unl.edu/usdaarsfacpub/1998

This Article is brought to you for free and open access by the U.S. Department of Agriculture: Agricultural Research Service, Lincoln, Nebraska at DigitalCommons@University of Nebraska - Lincoln. It has been accepted for inclusion in Publications from USDA-ARS / UNL Faculty by an authorized administrator of DigitalCommons@University of Nebraska - Lincoln. 


\title{
Correlation of $\alpha$-Amylase Inhibitor Content in Eastern Soft Wheats with Development Parameters of the Rice Weevil (Coleoptera: Curculionidae)
}

\author{
JAMES E. BAKER, STANLEY M. WOO, JAMES E. THRONE, AND \\ PATRICK L. FINNEY'
}

Stored Product Insects Research and Development Laboratory, USDA-ARS, Savannah, Georgia 31403

\begin{abstract}
Environ. Entomol. 20(1): 53-60 (1991)
ABSTRACT The $\alpha$-amylase inhibitor content in saline extracts of 104 Eastern soft wheat cultivars was determined by assay against a purified $\alpha$-amylase preparation from the rice weevil, Sitophilus oryzae (L.). A two-fold range of inhibitor levels, expressed as amylase inhibitor units per gram of dry weight $(\mathrm{AIU} / \mathrm{g})$, was found across all cultivars. Inhibitory activity was lowest in cultivar 'Augusta' $(5,084 \pm 124 \mathrm{AIU} / \mathrm{g})$ and highest in cultivar 'Logan' $(10,410 \pm 61 \mathrm{AIU} / \mathrm{g})$. No correlation of inhibitor content with progeny production $(r=$ $-0.161)$ or rate of emergence $(r=-0.292)$ was found among weevils reared on 30 cultivars having relatively low, medium, and high inhibitor levels, but there was a positive correlation between inhibitor content and average number of days to adult emergence $(r=0.569)$. Although mean development times were significantly different on cultivars with low and high AIU/g ( $35.9 \pm 0.2$ and $36.6 \pm 0.1 \mathrm{~d}$, respectively), the differences were only slight and indicated that, for these cultivars of soft wheats, $\alpha$-amylase inhibitors have little practical effect on initial population reductions. Nevertheless, based on a population model for $S$. oryzae developing on wheat at $25^{\circ} \mathrm{C}$ and $75 \% \mathrm{RH}$, the slight delay in mean development time $(0.7 \mathrm{~d})$ on cultivars with relatively high $\mathrm{AIU} / \mathrm{g}$ results in a $20.9 \%$ reduction in total number of weevils after $180 \mathrm{~d}$. Simulations also indicate that physical or biochemical resistance factors in wheat have to delay development time for about $6.2 \mathrm{~d}$ or reduce fecundity by about $40 \%$ to prevent wheat from being graded "weevily" $180 \mathrm{~d}$ after a single pair of weevils infests a hypothetical 6,000-bushel wheat bin.
\end{abstract}

KEY WORDS Insecta, wheat, amylase inhibitors, models

THE FUNCTIONAL ROLE of naturally occurring $\alpha$-amylase inhibitors found in wheat kernels is not clearly known. These low-molecular-weight, water-soluble proteins increase in concentration throughout seed development and reach a maximum concentration in mature kernels (Pace et al. 1978). Inhibitor content decreases rapidly after germination, and no activity is detected in developing coleoptiles or roots. The inhibitors, which make up about $65 \%$ of the albumin fraction ( $\mathrm{Pe}$ trucci et al. 1974), have been postulated to be storage proteins or to control starch metabolism within the kernels, even though there is no in vitro inhibition of the plant $\alpha$-amylases by these proteins (Marshall 1975, Buonocore et al. 1977, Richardson 1981). Because of the close association of inhibitors with polysaccharides in the wheat endosperm, Buonocore et al. (1977) hypothesized that an indirect metabolic control of starch metabolism could occur during kernel maturation by physically preventing access of the $\alpha$-amylases to starch granules.

Mention of a commercial or proprietary product does not constitute an endorsement by the USDA.

' Soft Wheat Quality Research Laboratory, USDA-ARS, Wooster, Ohio 44691.
They also postulated that, during germination, the albumins might promote water absorption, resulting in a detachment of inhibitors from the starch granules and subsequent access of starch to $\alpha$-amylase.

Another postulated role for $\alpha$-amylase inhibitors (as well as naturally occurring proteinase inhibitors) in cereals and legumes is that of providing a selective advantage through increased resistance to seed-eating insects (Silano et al. 1975, Buonocore et al. 1977, Richardson 1981), $\alpha$-Amylases of granivorous insects are particularly sensitive to $\alpha$-amylase inhibitors from wheat (Silano et al. 1975), and much of the research on biochemical interaction of enzymes and inhibitors has been done with these species, particularly Tenebrio molitor L. and Sitophilus oryzae (L.) (Shainkin \& Birk 1970; Buonocore et al. 1976, 1980, 1985; Baker 1988a, 1989; Baker \& Lum 1989). Although $\alpha$-amylase activity of $S$. oryzae feeding on whole wheat kernels is decreased relative to that of weevils feeding on other cereals (Baker 1988b), it is not known if these reductions in enzyme level result, either directly or indirectly, in significantly lower growth rates or rates of population development. Yetter et al. (1979) provided some evidence that progeny production 
of $S$. oryzae was reduced in wheat that had increased levels of inhibitory activity.

To further determine the potential of $\alpha$-amylase inhibitors in wheat as biochemical resistance factors against grain weevils, extracts prepared from. 104 eastern soft wheat cultivars were assayed for inhibitory activity against a partially purified $\alpha$-amylase preparation from $S$. oryzae. Correlations of inhibitor content with three population growth parameters (total progeny production, average number of days to adult emergence, and rate of development) were determined for weevils reared on 30 cultivars that contained relatively low, medium, and high levels of $\alpha$-amylase inhibitory activity. Because little information is available on how potential plant resistance factors, such as digestive enzyme inhibitors, affect insect population dynamics, a population model was developed for S. oryzae on wheat at $25^{\circ} \mathrm{C}$ and $75 \% \mathrm{RH}$. Simulations with the model were used to predict effects of developmental delays and decreased progeny production on numbers of weevils after $180 \mathrm{~d}$.

\section{Materials and Methods}

Wheat Cultivars. Whole wheat and finely-ground samples of 104 eastern soft wheat cultivars were obtained from the Soft Wheat Quality Research Laboratory, USDA-ARS, Wooster, Ohio. The $\alpha$-amylase inhibitor content was determined on the ground samples, and weevil development was measured in whole grain.

Extraction of Inhibitors. Four samples ( $1 \mathrm{~g}$ each) of each cultivar were weighed to the nearest 0.1 $\mathrm{mg}$, placed in $30-\mathrm{ml}$ glass centrifuge tubes, extracted for $2 \mathrm{~h}$ at room temperature with $5 \mathrm{ml} 0.15 \mathrm{M}$ $\mathrm{NaCl}$, and centrifuged for $20 \mathrm{~min}$ at $10,000-\times \mathrm{g}$. Supernatants were decanted into clean tubes, heated in a water bath at $70^{\circ} \mathrm{C}$ for $20 \mathrm{~min}$ (to destroy endogenous amylase activity), and recentrifuged for $20 \mathrm{~min}$. Final supernatants were diluted with $\mathrm{H}_{2} \mathrm{O}$ containing $0.5 \% \mathrm{BSA}$ (bovine serum albumin) and assayed for inhibitory activity (see below). Protein concentration was estimated with the procedure of Lowry et al. (1951) by using BSA as standard.

Dry Weights. Dry weights of the ground flour samples were determined by measuring moisture contents of parallel samples with AACC Method 44-15A (American Association of Cereal Chemists, Inc. 1969). For each cultivar, duplicate samples (2 g) were weighed to the nearest $0.1 \mathrm{mg}$, placed in tared aluminum moisture dishes, and heated at $130^{\circ} \mathrm{C}$ for $60 \mathrm{~min}$ in a mechanical convection oven. Dishes were held in desiccators over 8-12-mesh molecular sieves during cooling and before reweighing.

Purification of Rice Weevil $\alpha$-Amylase. $\alpha$-Amylase was partially purified from adult $S$. oryzae $(25.01 \mathrm{~g})$ by extraction with $1 \% \mathrm{NaCl}$, ammonium sulfate precipitation, glycogen complex formation, and chromatography on DEAE-Sephacel (Baker \& Woo 1985). After concentration, the final column sample contained $14.5 \mathrm{mg}$ protein in $5 \mathrm{ml} 20 \mathrm{mM}$ Tris $\cdot \mathrm{HCl} \mathrm{pH} 7.5$ and was composed of two amylase allozymes, Amy-1 and Amy-2 (Baker et al. 1990). Protein concentration was estimated as above. For the inhibition assay, aliquots of this sample were diluted so that $20 \mu \mathrm{l}$ contained $1 \mu \mathrm{g}$ protein.

Inhibition Assay. To determine appropriate extract concentrations for the assay, wheat extracts ('Blazer') were diluted 1:30, 1:40, 1:50, 1:60, 1:70, $1: 80$, and $1: 90$ with $0.05 \%$ aqueous BSA. The inhibition assay was slightly modified from Baker

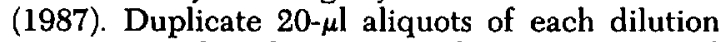
were preincubated at $30^{\circ} \mathrm{C}$ with $1 \mu \mathrm{g}$ rice weevil $\alpha$-amylase (20 $\mu \mathrm{l}$ of diluted sample) and $160 \mu \mathrm{l} 50$ $\mathrm{mM}$ acetate $\mathrm{pH} 5.0$ containing $20 \mathrm{mM} \mathrm{NaCl}$ and $0.1 \mathrm{mM} \mathrm{CaCl}$. After $30 \mathrm{~min}$, residual amylase activity was determined by adding $1 \mathrm{ml}$ of $1 \%$ starch in the acetate buffer containing $0.015 \%$ glucose (Hoorn \& Scharloo 1978). The reaction was stopped by adding $1 \mathrm{ml}$ dinitrosalicylic acid reagent (DNS), and color was developed by heating for $5 \mathrm{~min}$ in a boiling water bath. After dilution with $2 \mathrm{ml} \mathrm{H}_{2} \mathrm{O}$, absorbance was measured at $550 \mathrm{~nm}$. Maltose hydrate was used as standard.

Unit Definitions. One amylase inhibitor unit (AIU) was defined as the amount that inhibits one amylase unit (AU) by $50 \%$. One $\mathrm{AU}$ is the amount of enzyme that produces $1 \mathrm{mg}$ maltose hydrate/ $\min$ at $30^{\circ} \mathrm{C}$.

Calculations. Four cultivars (four replicates could be extracted and duplicate aliquots of each replicate assayed for inhibitory activity in $1 \mathrm{~d}$. Absorbance values of triplicate controls, duplicate inhibited samples of each cultivar replicate, blanks and standards, as well as fresh weight and moisture content data of each replicate, were determined. From these values, percentage inhibition was calculated and expressed as AIU per gram dry weight and AIU per milligram protein for each replicate of each cultivar.

Bioassay. Total progeny production, average time to adult emergence, and rate of emergence (Baker 1988c) were determined for S. oryzae reared on intact grain of cultivars with relatively low, medium, and high AIU levels. Of the 104 cultivars analyzed for AIU content, 30 cultivars were selected for bioassay, 10 cultivars for each of the three inhibitor groups.

Clear plastic snap-cap prescription vials ( 3.2 by $8 \mathrm{~cm}, 16$ dram) were used to rear weevils. A hole ( $1.9 \mathrm{~cm}$ diameter) was punched in each lid. Copper screen (\#40 mesh) was cut to fit snugly on the underside of each lid. This allowed air exchange and prevented escape of weevils.

Plastic containers ( 15 by 28 by $38 \mathrm{~cm}$ ) with lids were used to hold the rearing vials. Saturated $\mathrm{NaCl}$ (1 liter) was poured on the floor of each container to maintain the humidity at about $75 \%$ (Greenspan 1977). Plastic grids on the floor of each container elevated the vials $4 \mathrm{~cm}$ above the salt solution. These rearing chambers were held in darkness in an incubator maintained at $25^{\circ} \mathrm{C}$. 
For valid comparisons of weevil growth parameters, it is important to minimize differences in moisture content between cultivars. In these tests, moisture content of each tested cultivar was measured with a Motomco Model 919 moisture meter (Motomco Inc., Paterson, N.J.) and adjusted to 15\% with appropriate amounts of $\mathrm{H}_{2} \mathrm{O}$. Next, 25-g samples were placed in rearing vials (five replicates per cultivar) and equilibrated over saturated $\mathrm{NaCl}$ in rearing chambers for $10 \mathrm{wk}$. A total of 150 vials was prepared and randomly placed into three chambers. Additional bulk samples of each cultivar were similarly equilibrated and used to measure moisture content just before adding weevils.

About 3,000 2-3-wk-old adult S. oryzae (Savannah lab strain) were removed from stock cultures and placed on fresh wheat for 1 wk. Over a 3-d period, snout characteristics were used to select females from this group (Halstead 1963). Females were held in plastic Petri dishes containing wheat until needed.

To determine an appropriate oviposition period, 10 rearing vials containing $25-\mathrm{g}$ samples of laboratory wheat were equilibrated to $75 \% \mathrm{RH}$ as above. In preliminary tests, five female $S$. oryzae were allowed to oviposit at $25^{\circ} \mathrm{C}$ for $3 \mathrm{~d}$ (five vials) or 6 d (five vials), after which time the females were discarded. Vials were examined daily beginning 28 $\mathrm{d}$ after the middle oviposition day (day 0 ) of each time period. Emergent adults were removed and counted. Results indicated that the average number of days to emergence was $35.5 \pm 0.15(\bar{x} \pm \mathrm{SE})$ for the 3-d oviposition period and $35.6 \pm 0.15$ for the 6-d oviposition period. Mean progeny per replicate was $123.2 \pm 7.9$ ( 8.2 weevils per female-day) and $231.4 \pm 11.3$ (7.7 weevils per female-day) for the two time periods, respectively. Because of nearly identical growth parameters, cultivar comparisons were made with the 3-d oviposition period.

Statistical Analyses. Total progeny produced per replicate, average number of days to adult emergence, and rate of emergence (slope of cumulative emergence curve at average day; represented by reciprocal of cube root of variance about average day [Baker 1988c]) were calculated from daily emergence counts. Mean values of all growth parameters, mean values of AIU content of all cultivars, analyses of variance, mean separations, and correlations of weevil growth parameters with AIU content and grain moisture levels were determined with Proc ANOVA and Proc Corr (SAS Institute 1987, 1988). Mean comparisons were carried out with the Waller-Duncan Bayesian LSD (least significant difference) test (Waller \& Duncan 1969) in SAS. Significance of correlation coefficients was determined by adjusting for multiple comparisons with sequential Bonferroni $t$ tests (Rice 1989).

Model and Simulations. We used the model of Throne (1989) to predict whether observed changes in development rate or progeny production have practical significance. The model was modified to simulate rice weevil population dynamics in wheat at $25^{\circ} \mathrm{C}$ and $75 \% \mathrm{RH}$. Assumptions for the model are listed below.

Development from egg to adult emergence is $36.1 \pm 2.86 \mathrm{~d}$ (data from the present study, standard error estimated as in Shaffer [1983]). Adult male longevity is $116.1 \pm 50.89 \mathrm{~d}$ (Birch 1953). The female preoviposition period lasts $2.0 \pm 0.35$ d (data of Singh \& Soderstrom [1963], standard error estimated as in Shaffer [1983]). The adult female stage was split into reproductive females and nonreproductive females. Females reproduce for $98.0 \pm 5.9 \mathrm{~d}$ (data of Birch [1945], standard error estimated as in Shaffer [1983]). Each female lays 384 eggs during her lifetime (Birch 1945) at a constant daily rate. Nonreproducing females live an additional $21.0 \pm 1.9 \mathrm{~d}$ (data of Birch [1953], standard error estimated as in Shaffer [1983]). Survival of all stages is assumed to be $100 \%$ and adults emerged with a $1: 1$ sex ratio.

We started each simulation with a pair of newly emerged adults. Effects of delays up to $20 \mathrm{~d}$ in immature development and reductions to $50 \%$ in fecundity on total weevil population after $180 \mathrm{~d}$ were investigated. Simulation results were applied to a hypothetical weevil infestation in a 6,000 -bushel bin.

\section{Results}

Inhibition Assays. A 1:50 dilution of wheat extract $(1 \mathrm{~g}$ extracted with $5 \mathrm{ml} 0.15 \mathrm{M} \mathrm{NaCl})$ gave about $55 \%$ inhibition of $\alpha$-amylase from S. oryzae with our assay conditions. In previous studies, a 1:30 dilution was used to assay wheat extracts ( $\mathrm{Ba}$ ker 1988b); however, the presence of BSA in the preincubation mixture increases the sensitivity of the assay (Baker 1988a). Inhibition levels obtained with the 1:50 dilution were considered appropriate for the range of expected inhibition values and for extrapolation of results across all cultivars.

Based on assays with the 1:50 dilution of crude extract, a 2 -fold range of $\alpha$-amylase inhibitory activity was found among the 104 soft wheats tested. Cultivar 'Augusta' had the lowest mean activity $(5,084 \pm 124(\bar{x} \pm \mathrm{SE}) \mathrm{AIU} / \mathrm{g}, n=12)$ and 'Logan' had the highest activity $(10,410 \pm 61 \mathrm{AIU} / \mathrm{g}, n=$ 8). Inhibitory activity in cultivar 'Logan' was significantly higher ( 0.05 level) than that found in all other cultivars. Between the low and high extremes of 'Augusta' and 'Logan,' there was an incremental increase in inhibitory activity among the remaining 102 cultivars. When activities were based on protein concentration rather than dry weight, 'Logan' again had the highest activity $(535 \pm 20 \mathrm{AIU} /$ mg protein) whereas 'Pacer' had the lowest activity (200 $\pm 5 \mathrm{AIU} / \mathrm{mg}$ protein). 'Augusta' had a relatively low activity level of $232 \pm 15 \mathrm{AIU} / \mathrm{mg}$ protein. Across all replicates and cultivars, inhibition ranged from 23.7 to $82.4 \%$, and protein content of diluted wheat extracts used in preincubation mixtures ranged from 1.19 to $2.49 \mu \mathrm{g}$. There was little correlation between protein content and per- 
Table 1. Growth parameters of $S$. oryane reared at $25^{\circ} \mathrm{C}$ and $75 \%$ RH on 30 selected cultivars of eastern soft wheats with relatively low, medium, and high a-amylase inhibitor levels

\begin{tabular}{|c|c|c|c|c|c|c|}
\hline \multirow{2}{*}{ Cultivar ${ }^{a}$} & \multirow{2}{*}{$\operatorname{Rank}^{b}$} & \multirow{2}{*}{$\mathrm{AIU}^{c}$} & \multirow{2}{*}{$\mathrm{AIU}^{l}$} & \multicolumn{3}{|c|}{ Growth parameter } \\
\hline & & & & Total $^{e}$ & Avedayf & Rateg \\
\hline Auburn & $\mathbf{L}$ & $238 \pm 08$ & $5,746 \pm 144$ & $133.4 \pm 4.5$ & $35.8 \pm 0.1$ & $0.75 \pm 0.01$ \\
\hline Augusta & L & $232 \pm 15$ & $5,084 \pm 124$ & $120.0 \pm 4.3$ & $35.4 \pm 0.2$ & $0.79 \pm 0.01$ \\
\hline Doublecrop & $\mathbf{L}$ & $237 \pm 09$ & $5,738 \pm 216$ & $134.2 \pm 8.6$ & $36.5 \pm 0.3$ & $0.65 \pm 0.03$ \\
\hline Hart & $\mathbf{L}$ & $252 \pm 04$ & $6,078 \pm 065$ & $117.8 \pm 9.7$ & $36.6 \pm 0.2$ & $0.75 \pm 0.03$ \\
\hline Harus & $\mathrm{L}$ & $246 \pm 07$ & $5,123 \pm 231$ & $141.6 \pm 7.6$ & $35.8 \pm 0.2$ & $0.72 \pm 0.03$ \\
\hline Holley & $\mathrm{L}$ & $279 \pm 04$ & $6,047 \pm 096$ & $133.0 \pm 4.1$ & $36.3 \pm 0.1$ & $0.64 \pm 0.01$ \\
\hline NY $6432-10$ & $\mathrm{~L}$ & $231 \pm 06$ & $5,905 \pm 030$ & $135.2 \pm 7.7$ & $35.9 \pm 0.2$ & $0.64 \pm 0.02$ \\
\hline Pacer & $\mathbf{L}$ & $200 \pm 05$ & $5,504 \pm 042$ & $133.6 \pm 7.2$ & $35.2 \pm 0.3$ & $0.79 \pm 0.02$ \\
\hline Pioneer S-76 & L & $205 \pm 04$ & $5,330 \pm 087$ & $132.2 \pm 5.4$ & $35.5 \pm 0.2$ & $0.76 \pm 0.02$ \\
\hline Purcell & $\mathbf{L}$ & $257 \pm 03$ & $5,953 \pm 122$ & $142.8 \pm 4.9$ & $35.7 \pm 0.3$ & $0.73 \pm 0.02$ \\
\hline Adena & $\mathbf{M}$ & $302 \pm 09$ & $7,076 \pm 174$ & $135.8 \pm 10.8$ & $35.7 \pm 0.2$ & $0.79 \pm 0.01$ \\
\hline Bradford & $M$ & $259 \pm 02$ & $6,697 \pm 043$ & $122.2 \pm 5.0$ & $36.4 \pm 0.2$ & $0.69 \pm 0.02$ \\
\hline Coker 916 & $\mathrm{M}$ & $283 \pm 08$ & $6,699 \pm 148$ & $128.2 \pm 6.6$ & $35.7 \pm 0.2$ & $0.69 \pm 0.01$ \\
\hline Downy & $\mathrm{M}$ & $276 \pm 06$ & $7,070 \pm 088$ & $138.6 \pm 4.7$ & $35.8 \pm 0.1$ & $0.73 \pm 0.01$ \\
\hline Florida 301 & $\mathbf{M}$ & $325 \pm 09$ & $7,116 \pm 171$ & $142.2 \pm 8.2$ & $35.5 \pm 0.1$ & $0.72 \pm 0.01$ \\
\hline Frankenmuth & $M$ & $272 \pm 09$ & $6,784 \pm 274$ & $136.4 \pm 11.0$ & $35.5 \pm 0.2$ & $0.78 \pm 0.02$ \\
\hline Hunter & $\mathbf{M}$ & $342 \pm 05$ & $7,150 \pm 231$ & $105.8 \pm 8.4$ & $36.5 \pm 0.2$ & $0.68 \pm 0.02$ \\
\hline Nelson & $\mathbf{M}$ & $311 \pm 06$ & $7,006 \pm 082$ & $124.6 \pm 5.9$ & $35.7 \pm 0.2$ & $0.74 \pm 0.02$ \\
\hline Pioneer 2551 & $\mathbf{M}$ & $288 \pm 06$ & $6,968 \pm 058$ & $127.0 \pm 7.1$ & $35.7 \pm 0.1$ & $0.67 \pm 0.01$ \\
\hline Scotty & $\mathbf{M}$ & $294 \pm 05$ & $6,890 \pm 058$ & $138.4 \pm 2.6$ & $36.3 \pm 0.3$ & $0.76 \pm 0.02$ \\
\hline Callahan 115 & $\mathbf{H}$ & $266 \pm 03$ & $7,923 \pm 070$ & $135.4 \pm 5.3$ & $36.9 \pm 0.2$ & $0.65 \pm 0.03$ \\
\hline Cardinal & $\mathbf{H}$ & $347 \pm 08$ & $8,456 \pm 114$ & $132.0 \pm 4.5$ & $36.2 \pm 0.1$ & $0.68 \pm 0.03$ \\
\hline Clarkan & $\mathbf{H}$ & $277 \pm 02$ & $8,320 \pm 036$ & $123.6 \pm 5.5$ & $36.5 \pm 0.2$ & $0.64 \pm 0.02$ \\
\hline Coker 747 & $\mathbf{H}$ & $304 \pm 04$ & $8,780 \pm 028$ & $148.8 \pm 5.8$ & $36.1 \pm 0.2$ & $0.76 \pm 0.01$ \\
\hline Coker 68-15 & $\mathbf{H}$ & $337 \pm 04$ & $9,036 \pm 055$ & $123.2 \pm 6.0$ & $37.5 \pm 0.2$ & $0.61 \pm 0.01$ \\
\hline Coker 9227 & $\mathbf{H}$ & $325 \pm 07$ & $8,070 \pm 153$ & $129.6 \pm 5.9$ & $36.8 \pm 0.3$ & $0.69 \pm 0.01$ \\
\hline Florida 302 & $\mathbf{H}$ & $346 \pm 04$ & $8,432 \pm 219$ & $141.8 \pm 7.5$ & $35.9 \pm 0.2$ & $0.72 \pm 0.01$ \\
\hline Logan & $\mathbf{H}$ & $535 \pm 20$ & $10,410 \pm 061$ & $107.2 \pm 8.2$ & $36.6 \pm 0.2$ & $0.74 \pm 0.02$ \\
\hline Roy & $\mathbf{H}$ & $337 \pm 01$ & $8,029 \pm 015$ & $144.6 \pm 4.8$ & $36.6 \pm 0.3$ & $0.66 \pm 0.01$ \\
\hline Saluda & $\mathbf{H}$ & $351 \pm 03$ & $7,959 \pm 034$ & $130.4 \pm 7.8$ & $36.5 \pm 0.4$ & $0.66 \pm 0.02$ \\
\hline
\end{tabular}

a Selection of eastern soft wheat cultivars for bioassay was based on amount of $\alpha$-amylase inhibitor (AIU/g) present in each of the original 104 cultivars.

${ }^{b}$ Relative amount of $\alpha$-amylase inhibitor; L, low; M, medium; H, high. Cultivars are listed alphabetically within each group.

' Amylase inhibitor units per milligram protein. Mean $\pm \mathrm{SE}$ of 4 replicates per cultivar. Note: Values for 'Augusta' and 'Harus' are based on 12 replicates; values for 'Logan' are based on 8 replicates.

${ }^{d} \alpha$-Amylase inhibitor units per gram wheat (dry wt). Mean $\pm \mathrm{SE}$ of 4 replicates per cultivar. Note: Values for 'Augusta' and 'Harus' are based on 12 replicates; values for 'Logan' are based on 8 replicates. Mean coefficient of variation for all 104 cultivars was 3.1\%.

e Total progeny produced per replicate (each replicate consisted of five females ovipositing for $3 \mathrm{~d}$ on $25 \mathrm{~g}$ wheat). Mean $\pm \mathrm{SE}$ of five replicates per cultivar. Mean coefficient of variation was $11.2 \%$ (range, 4.1-18.5\%).

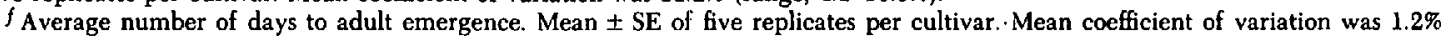
(range, $0.4-2.3 \%$ )

$g$ Rate of emergence ( $1 /$ variance $^{0.333333}$ ). Mean $\pm \mathrm{SE}$ of five replicates per cultivar. Mean coefficient of variation was $5.2 \%$ (range, $2.0-11.1 \%)$.

centage inhibition $(r=0.11)$, but there was a larger correlation $(r=0.67)$ between specific inhibitory activity based on dry weight and that based on protein. Ten cultivars with lowest (range, 5,0846,078 AIU/g), medium (range, 6,697-7,150 AIU/ $\mathrm{g}$ ), and highest inhibition activity (range, 7,932$10,410 \mathrm{AIU} / \mathrm{g}$ ) were selected for bioassay.

Results of inhibition assays of cultivars not bioassayed are listed below in ascending order within three general ranges of inhibitor content. Range 5,000-6,500 AIU/g: 'Houser,' 'Ticonderoga,' 'GR 863,' 'GR 855,' 'Favor,' 'Stacy,' 'Hillsdale,' 'Geneva, 'Rosen,' 'HW 3015, 'Twain, 'Pioneer 2553,' 'Omega 78,' 'Coker P9323,' 'Potomac,' 'Redcoat,' 'Trumbell,' 'Pioneer 2550,' 'GR 860,' 'Becker, "Arthur 71,' 'Fredric,' 'Coker 833,' 'Ionia,' 'Gordon,' 'Key, 'Genessee,' and 'McNair 1813.' Range 6,5017,500 AIU/g: 'Arrow,' 'Dancer,' 'SR 82,' 'Oasis,'
'Pioneer S78,' 'Titan,' 'Arthur,' 'Tyler,' 'Fillmore,' 'Kenosha,' 'Delta Queen,' 'Thorne,' 'SR 49,' 'Blackhawk,' 'Coker 797,' 'Fairfield,' 'JMS 222,' 'Coker 983,' 'Argee,' 'Vigo,' 'Ruler,' 'Charmany,' 'HW 3021, 'Roland,' and 'Caldwell.' Range 7,501-10,000 AIU/g: 'Ross,' 'Monon,' 'Severn,' 'Beau,' 'Coker 9733, ' Yorkstar, 'Tecumseh, 'Knox 62, "Wheeler,' 'Coker 762, 'Sullivan, 'Abe, 'HW 3022, 'Lincoln," 'Terral 81-17,' 'Blazer,' 'Massey,' 'Southern Belle,' 'Chancellor,' 'Feland,' and 'McNair 1003.'

Bioassay-Weevil Growth Parameters. Values for three growth parameters of $S$. oryzae reared on the 30 selected wheat cultivars as well as the inhibitor content of these same cultivars are given in Table 1. Ranges within each parameter for weevils reared on wheat with relatively low, medium, and high AIU per gram levels, respectively, were: total progeny, 117.8-142.8, 105.8-142.2, and 107.2- 


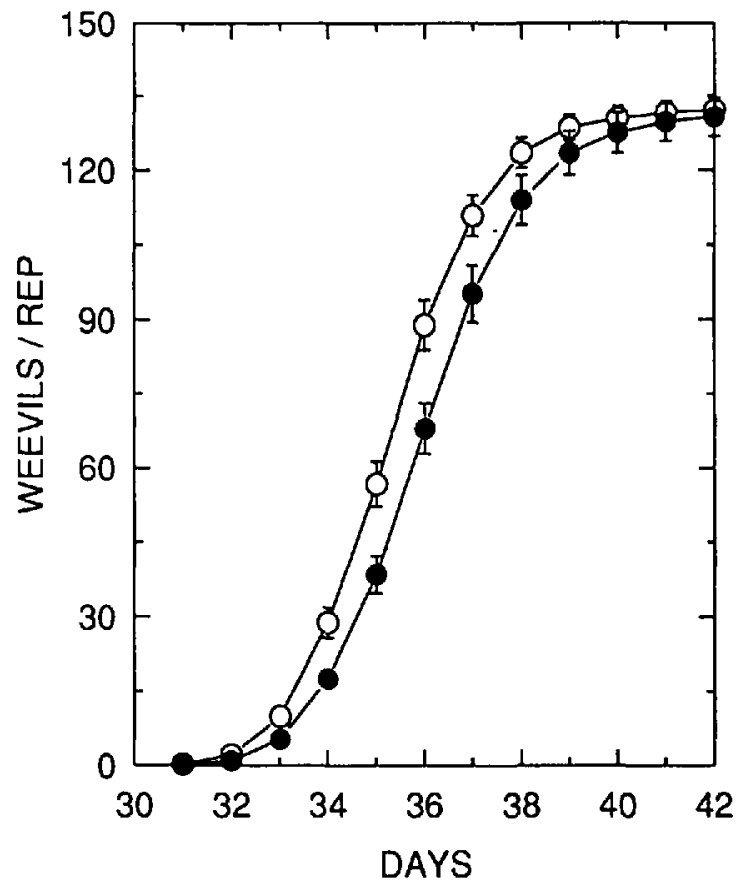

Fig. 1. Cumulative emergence patterns and total progeny production of $S$. oryzae reared at $25^{\circ} \mathrm{C}$ and $75 \%$ RH on selected wheat cultivars grouped according to relatively low $\alpha$-amylase inhibitor content $(0)$ and relatively high $\alpha$-amylase inhibitor content (O). Each point is the mean of 10 cultivars per group (five replicates per cultivar). Error bars are $\mathrm{SE}$ values. Wheat was equilibrated for 10 wk over saturated $\mathrm{NaCl}$ before use.

148.8; average days to emergence, 35.2-36.6, 35.536.5 , and $35.9-37.5$; and rate, $0.64-0.79,0.67-0.79$, and $0.64-0.76$.

Although ranges of growth parameters were similar among cultivars within each inhibitor group, there were significant differences among growth parameters on individual cultivars (Table 1). For the variable Total: $F=2.20 ; \mathrm{df}=29,120 ; P=$ $0.0016 ; \mathrm{LSD}=23.5$. For the variable Aveday: $F=$ $6.21 ; \mathrm{df}=29,120 ; P=0.0001 ; \mathrm{LSD}=0.6$. For the variable Rate: $F=8.03 ; \mathrm{df}=29,120 ; P=0.0001$;
$\mathrm{LSD}=0.05$. Aveday for weevils reared on 'Coker 68-15,' a cultivar with relatively high AIU per gram, was the only parameter that was significantly different $(0.05$ level) from those obtained on all other cultivars.

Mean values of the three growth parameters of $S$. oryzae are summarized by inhibitor grouping (low, medium, and high) in Table 2. There was no significant difference for the variables Total $(F=$ $0.15 ; \mathrm{df}=2,27 ; P=0.86)$ or Rate $(F=2.49 ; \mathrm{df}$ $=2,27 ; P=0.10$ ) within the three groups. However, there was a slight but significant 0.7 -d delay in development time for weevils reared on wheat cultivars with relatively high AIU per gram $(F=$ 6.63 ; $\mathrm{df}=2,27 ; P=0.0046$ ). Cumulative emergence curves for weevils reared on cultivars with relatively low and high AIU per gram (Fig. 1) reflect these developmental differences. Mean progeny production for $S$, oryzae across all 30 cultivars was 8.8 weevils per female-day.

Correlation of $\alpha$-Amylase Inhibition, with Growth Parameters. There was low correlation between levels of $\alpha$-amylase inhibition among all 30 wheat cultivars and total progeny production or rate of emergence of S. oryzae (Table 3). There was a positive correlation between AIU content and Aveday ( $r=0.568)$. Again, this reflects the small but significant delay in development time for weevils reared on cultivars with high AIU per gram. The negative correlation between Aveday and Rate $(r=-0.705)$ is an indication of the increased variance about average day for longer development times.

There was a low correlation between cultivar moisture content (analyzed just before testing) and the three growth parameters for S. oryzae. Coefficients $(r)$ for Total, Aveday, and Rate were 0.059 , 0.129 , and -0.228 , respectively. Mean $( \pm \mathrm{SE})$ moisture content for all 30 cultivars was $14.20 \pm 0.08 \%$ (range, 13.45-14.89\%).

Simulations. Based on simulations with the $S$. oryzae model, a total of $1,598,000$ weevils would be present after a 180-d infestation in wheat at a constant $25^{\circ} \mathrm{C}$ and $14 \%$ moisture content (Table 4). If the single-pair infestation occurred in a 6,000 bushel bin, the infestation would consist of 266

Table 2. Summary of growth parameters of $S$. oryzae reared at $25^{\circ} \mathrm{C}$ and $75 \%$ RH on eastern soft wheat cultivars grouped according to $\alpha$-amylase inhibitor content

\begin{tabular}{lllll}
\hline \hline Cultivar group & & & & Growth parameter \\
& AIU $/ \mathrm{g}^{b}$ & Total $^{c}$ & Aveday $^{d}$ & Rate $^{e}$ \\
\hline Low & & $132.4 \pm 7.9 \mathrm{a}$ & $35.9 \pm 0.5 \mathrm{a}$ & $0.72 \pm 0.06 \mathrm{a}$ \\
Medium & $5,651 \pm 370 \mathrm{a}$ & $129.9 \pm 10.8 \mathrm{a}$ & $35.9 \pm 0.4 \mathrm{a}$ & $0.73 \pm 0.04 \mathrm{a}$ \\
High & $6,945 \pm 169 \mathrm{~b}$ & $131.6 \pm 12.1 \mathrm{a}$ & $36.6 \pm 0.4 \mathrm{~b}$ & $0.68 \pm 0.05 \mathrm{a}$ \\
\hline
\end{tabular}

Means within columns followed by the same letter are not significantly different $(P=0.05$; Proc ANOVA, SAS Institute [1987]); based on 10 cultivars, five replicates per cultivar.

a Each group, ranked by AIU content, was composed of 10 eastern soft wheat cultivars.

${ }^{b}$ Amylase inhibitor units per gram wheat (dry wt). Mean \pm SD based on 10 cultivars, four replicates per cultivar.

c Total progeny per replicate (each replicate consisted of five females ovipositing for $3 \mathrm{~d}$ on $25 \mathrm{~g}$ wheat).

$d$ Average number of days to adult emergence.

Rate $=1 /$ variance ${ }^{0.33333}$. 
Table 3. Correlation analysis of $\alpha$-amylase inhibitor content (AIU/g) with development parameters of S. oryzat reared at $25^{\circ} \mathrm{C}$ and $75 \% \mathrm{RH}$ on 30 selected cultivars of eastern soft wheats

\begin{tabular}{lcccc}
\hline \multirow{2}{*}{ Parameter } & \multicolumn{4}{c}{ Pearson correlation coefficients $^{a}$} \\
\cline { 2 - 5 } & AIU $^{b}$ & Total $^{c}$ & Aveday $^{d}$ & Rate $^{e}$ \\
\hline \multirow{2}{*}{ AIU } & 1.0 & -0.165 & $0.569^{*}$ & -0.292 \\
& 0.0 & 0.397 & 0.001 & 0.117 \\
\multirow{2}{*}{ Total } & - & 1.0 & -0.336 & 0.108 \\
& - & 0.0 & 0.069 & 0.569 \\
\multirow{2}{*}{ Aveday } & - & - & 1.0 & $-0.705^{*}$ \\
& - & - & 0.0 & 0.0001 \\
\multirow{2}{*}{ Rate } & - & - & - & 1.0 \\
& - & - & - & 0.0 \\
\hline
\end{tabular}

a Correlation coefficients $(r)$ and probabilities that $r$ is different from 0 (lower numbers) are given for each cell (Proc Corr, SAS Institute [1988]). Asterisk indicates significance at the 0.05 tablewise error level $(\alpha / k=0.00833)$.

${ }^{b}$ Amylase inhibitor units per gram wheat.

c Total progeny per replicate.

$d$ Average number of days to adult emergence.

- Rate of emergence (1/variance 0.333333 ).

weevils/bu. Surprisingly, the simulated 0.7 -d delay that was found in weevil development on cultivars with high AIU per gram results in a $20.9 \%$ reduction in population size. Delays in mean development time $>2 \mathrm{~d}$ result in $>50 \%$ reduction in total number of weevils.

Although levels of $\alpha$-amylase inhibitors did not affect fecundity in this study, reductions in fecundity also dramatically affect population size. A decrease in fecundity of $28.9 \%$ (difference between highest and lowest number of progeny on cultivars in this study) predicts that a $69 \%$ reduction in number of weevils would occur. Based on the model, a combined 0.7-d delay in development time and $28.9 \%$ reduction in fecundity results in a $\mathbf{7 4 . 9 \%}$ population reduction after $180 \mathrm{~d}$.

\section{Discussion}

For a valid comparison of ability of wheat cultivars to support rice weevil development and subsequent population growth, it is important to control behavioral factors that affect oviposition. In our studies, an oviposition rate at a density of five females per $25 \mathrm{~g}$ wheat results in production of 8.8 weevils per female-day. This compares favorably with the density-dependent optimum rate of about seven weevils per female-day described for S. oryzae by Longstaff (1981). A second important factor in the bioassay is control of moisture content. Cultivar differences in equilibrium moisture content were expected. However, the small measured differences apparently had little effect because there were no significant correlations of moisture content with any growth parameter. For both factors (density effects and moisture content), we feel that our bioassay procedure is not limiting and that differences in weevil growth parameters reflect cultivar effects.
Table 4. Effects of simulated developmental delays and reduced fecundity on total numbers of $S$. oryzae reared on wheat for $180 \mathrm{~d}$ at $25^{\circ} \mathrm{C}$ and $75 \%$ RH and extrapolation to a weevil population in a 6,000 -bushel bin ${ }^{a}$

\begin{tabular}{cccc}
\hline $\begin{array}{c}\text { Delay (d) } \\
\text { or fecundity } \\
\text { decrease }^{c}\end{array}$ & $\begin{array}{c}\text { Population } \\
\text { in 1,000's }\end{array}$ & Reduction, \%e & Weevils/buf \\
\hline \multicolumn{4}{c}{ Developmental delays } \\
0 & 1,598 & 0 & 266 \\
0.5 & 1,350 & 15.5 & 225 \\
1 & 1,144 & 28.4 & 191 \\
2 & 833 & 47.9 & 139 \\
5 & 388 & 75.7 & 65 \\
10 & 149 & 90.6 & 25 \\
20 & 18 & 98.9 & 3 \\
& Fecundity decrease & \\
5 & 1,336 & 16.4 & 222 \\
10 & 1,108 & 30.7 & 184 \\
20 & 738 & 53.8 & 123 \\
30 & 468 & 70.7 & 78 \\
40 & 279 & 82.5 & 47 \\
50 & 152 & 90.4 & 25 \\
\hline
\end{tabular}

a Based on the population model of Throne (1989) modified to fit $S$. oryzae.

${ }^{b}$ Delay relative to 36.1 days.

$c$ Percent decrease.

d Total number of weevils after $180 \mathrm{~d}$

Peduction based on population with no developmental delay.

$f$ Number of weevils per bushel wheat, based on an initial singlepair infestation.

Yetter et al. (1979) tested 50 geographic samples of five wheat cultivars for inhibition of $S$. oryzae amylase and for total progeny production. For 10 samples of 'Centurk,' progeny production was negatively correlated to $\alpha$-amylase inhibition $\langle r=$ -0.699 ), even though there was only a 1.3 -fold difference in inhibition between the highest and lowest value. In their assay, six females and three males were caged on 100 kernel samples for $7 \mathrm{~d}$. Mean progeny production of samples of 'Centurk' at $26^{\circ} \mathrm{C}$ and $60 \% \mathrm{RH}$ was 29.7 weevils per replicate or about 0.7 weevils per female-day. This relatively low level of oviposition indicates some weevil $x$ weevil interaction that may mask cultivar differences or give misleading results.

In the present study, we demonstrated that there is at least a 2 -fold range of $\alpha$-amylase inhibitory activity among cultivars of eastern soft wheats examined. However, among these cultivars, levels of $\alpha$-amylase inhibitors had only a slight effect on immature weevil development time and had no significant effect on population size after one generation. Although there may be a threshold concentration of inhibitory activity required before weevil fecundity and development time are more significantly affected, that concentration was not reached in these studies among these cultivars.

The potential of naturally occurring $\alpha$-amylase inhibitors in cereals as resistance factors is unclear. Although only slight development delays $(<1 \mathrm{~d}$ ) attributable to inhibitor level were found for $S$. oryzae, the model indicates that these slight delays in development time can reduce the total popu- 
lation by about $20 \%$ after $180 \mathrm{~d}$, the typical storage time for stored wheat. Simulations with the model indicate that relatively short developmental delays of 2-3 d can result in more substantial population reductions. From the data in Table 4, it is estimated that a 6.2-d delay (or a $40 \%$ reduction in fecundity) results in a population of about 54 weevils per bushel after $180 \mathrm{~d}$ (based on a single-pair infestation in a 6,000 -bushel bin). This weevil density is proportional to 2 live weevils $/ 500 \mathrm{~g}$ wheat, the threshold established by the Federal Grain Inspection Service (USDA-FGIS 1988). Above this threshold value, grain is considered "weevily." It remains to be seen if the inhibitor content (or amount of any other naturally occurring resistance factor in wheat) can be genetically modified to result in developmental delays or reductions in fecundity (or both) of the magnitude required for these more practical benefits.

\section{References Cited}

American Association of Cereal Chemists. 1969. Approved methods of the American Association of Cereal Chemists. American Association of Cereal Chemists, Inc.,, St. Paul, Minn.

Baker, J. E. 1987. Purification of isoamylases from the rice weevil, Sitophilus oryzae (L.) (Coleoptera: Curculionidae), by high-performance liquid chromatography and their interaction with partially-purified amylase inhibitors from wheat. Insect Biochem. 17: 37-44.

1988a. Purification of an $\alpha$-amylase inhibitor from wheat, Triticum aestivum, and its interaction with amylases from the rice weevil, Sitophilus oryzae (Coleoptera: Curculionidae). Insect Biochem. 18: 107116.

1988b. Dietary modulation of $\alpha$-amylase activity in eight geographical strains of Sitophilus oryzae and Sitophilus zeamais. Entomol. Exp. Appl. 46: 47-54.

1988c. Development of four strains of Sitophilus ory$z a e$ (L.) (Coleoptera: Curculionidae) on barley, corn (maize), rice, and wheat. J. Stored Prod. Res. 24: 193198.

1989. Interaction of inhibitor-0.12 from wheat with two amylase isozymes from the rice weevil, Sitophilus oryzae (Coleoptera: Curculionidae). Comp. Biochem. Physiol. 92B: 389-393.

Baker, J. E. \& P. T. M. Lum. 1989. Multiplicity of albumins from wheat inhibitory to amylase from the rice weevil (Coleoptera: Curculionidae). J. Econ. Entomol. 82: 1548-1553.

Baker, J. E. \& S. M. Woo. 1985. Purification, partial characterization, and postembryonic levels of amylases from Sitophilus oryzae and Sitophilus granarius. Arch. Insect Biochem. Physiol. 2: 415-428.

Baker, J. E., W. R. Halliday \& P. T. M. Lum. 1990. Genetics of $\alpha$-amylase in the rice weevil Sitophilus oryzae (L.) (Coleoptera: Curculionidae). J. Stored Prod. Res. 26: 7-10.

Birch, L. C. 1945. The influence of temperature, humidity and density on the oviposition of the small strain of Calandra oryzae L. and Rhizopertha dominica Fab. (Coleoptera). Aust. J. Exp. Biol. Med. Sci. 23: 197-203.

1953. Experimental background to the study of the distribution and abundance of insects. I. The influence of temperature, moistıre and food on the innate capacity for increase of three grain beetles. Ecology 34: 698-711.

Buonocore, V., E. Poerio, W. Pace, T. Petrucci, V. Silano \& M. Tomasi. 1976. Interaction of Tenebrio molitor L. $\alpha$-amylase with a wheat flour protein inhibitor. Fed. Eur. Biochem. Soc. Letters 67: 202206.

Buonocore, V., T. Petrucei \& V. Silano. 1977. Wheat protein inhibitors of $\alpha$-amylase. Phytochemistry 16: 811-820.

Buonocore, V., F. Gramenzi, W. Pace, T. Petrucei, E. Poerio \& V. Silano. 1980. Interaction of wheat monomeric and dimeric protein inhibitors with $\alpha$-amylase from yellow mealworm (Tenebrio molitor L. larva). Biochem. J. 187: 637-645.

Buonocore, V., M. DeBiasi, P. Giardina, E. Poerio \& V. Silano. 1985. Purification and properties of an $\alpha$-amylase tetrameric inhibitor from wheat kernel. Biochim. Biophys. Acta 831: 40-48.

Greenspan, L. 1977. Humidity fixed points of binary saturated aqueous solutions. Natl. Bur. Stand., J. Res,, Sect. A 81: 89-96.

Halstead, D. G. H. 1963. External sex differences in stored-products Coleoptera. Bull. Entomol. Res. 54: 119-134.

Hoorn, A. J. W. \& W. Scharloo. 1978. The functional significance of amylase polymorphism in Drosaphila melanogaster l. Properties of two amylase variants. Genetica 49: 173-180.

Longstaff, B. C. 1981 . Biology of the grain pest species of the genus Sitophilus (Coleoptera: Curculionidae): a critical review. Prot. Ecol. 2: 83-130.

Lowry, 0. H., N. J. Rosebrough, A. L. Farr \& R. J. Randall. 1951. Protein measurement with the Folin phenol reagent. J. Biol. Chem. 193: 265-275.

Marshall, J. J. 1975. $\alpha$-Amylase inhibitors from plants. Am. Chem. Soc. Symp. Ser. 15: 244-266.

Pace, W., R. Parlamenti, A. Rab, V. Silano \& L. Vittozzi. 1978. Protein $\alpha$-amylase inhibitors from wheat Alour. Cereal Chem. 55: 244-254.

Petrucci, T., M. Tomasi, P. Cantagalli \& V. Silano. 1974. Comparison of wheat albumin inhibitors of $\alpha$-amylase and trypsin. Phytochemistry 13: 2487-2495.

Fice, W. R. 1989. Analyzing tables of statistical tests. Evolution 43: 223-225.

Richardson, M. 1981. Protein inhibitors of enzymes. Food Chem. 6: 235-253.

SAS Institute. 1987. SAS/STAT guide for personal computers, version 6 ed. SAS Institute, Cary, N.C.

1988. SAS procedures guide, release $6.03 \mathrm{ed}$. SAS Institute, Cary, N.C.

Shaffer, P. L. 1983. Prediction of variation in development period of insects and mites reared at constant temperatures. Environ. Entomol. 12: 1012-1019.

Shainkin, R. \& Y. Birk. 1970. $\alpha$-Amylase inhibitors from wheat-isolation and characterization. Biochim. Biophys. Acta 221; 502-513.

Silano, V., M. Furia, L. Gianfreda, A. Macri, R. Palescandolo, A. Rab, V. Scardi, E. Stella \& F. Valfre. 1975. Inhibition of amylases from different origins by albumins from the wheat kernel. Biochim. Biophys. Acta 391: 170-178.

Singh, S. R. \& E. L. Soderstrom. 1963. Sexual maturity of the rice weevil, Sitophilus oryzae (L.) as indicated by sperm transfer and viable eggs. J. Kans. Entomol. Soc. 36: 32-34.

Throne, J. E. 1989. Effects of non-catastrophic control 
technologies that alter life history parameters on insect population growth: a simulation study. Environ. Entomol. 18: 1050-1055.

USDA-FGIS. 1988. Official United States standards for grain. USDA, Federal Grain Inspection Service, 7 CFR Part 810.

Waller, R. A. \& D. B. Duncan. 1969. A Bayes rule for the symmetric multiple comparison problem. J. Am. Stat. Assoc. 64: 1484-1499.
Yetter, M. A., R. M. Saunders \& H. P. Boles. 1979. $\alpha$-Amylase inhibitors from wheat kernels as factors in resistance to postharvest insects. Cereal Chem. 56: 243-244.

Received for publication 18 May 1990; accepted 28 August 1990. 